\title{
Transcriptional Enhancers: Bridging the Genome and Phenome
}

\author{
Bing Ren ${ }^{1}$ AND Feng YuE ${ }^{2}$ \\ ${ }^{1}$ Ludwig Institute for Cancer Research, University of California, San Diego School of Medicine, \\ Department of Cellular and Molecular Medicine, Institute of Genomic Medicine, and Moores \\ Cancer Center, La Jolla, California 92093-0653 \\ ${ }^{2}$ Department of Biochemistry and Molecular Biology and Institute for Personalized Medicine, \\ Pennsylvania State University College of Medicine, Hershey, Pennsylvania 17033
}

Correspondence: biren@ucsd.edu

\begin{abstract}
Enhancers play a major role in animal development by modulating spatiotemporal expression of genes. They interact with sequence-specific transcriptional regulators in response to internal and external cues to bring about transcriptional changes, thus serving as the critical link between an organism's genome and its phenotypic traits. Deciphering the biology of enhancers is a key to understanding the genetic basis of common human diseases. Although a large number of candidate enhancers have been annotated through genome-wide analyses of chromatin accessibility, transcription factor binding, and histone modification in diverse cell types, efforts to characterize their biological roles in human diseases have only begun. Recent experiments have suggested a role for the three-dimensional chromatin architecture in regulation of gene expression by enhancers.
\end{abstract}

The genome of each person differs from one another at millions of nucleotides, and these sequence variants together are responsible for the spectrum of phenotypic traits and disease risks of that individual (Carlson et al. 2004). Although it has become commonplace these days to sequence one's genome, predicting the specific phenotypic traits of each individual from DNA still seems an insurmountable challenge. This is because $>98 \%$ of the human genome is non-protein-coding and generally without a clearly defined biological function (Lander 2011). On the other hand, these "junk DNAs," as previously called, have now been shown to harbor numerous functional elements with important roles in gene regulation and disease pathogenesis (ENCODE Project Consortium 2012). In particular, scattered in these sequences are millions of putative cis-regulatory elements responsible for spatiotemporal gene expression during development. Furthermore, a large number of sequence variants in the cis-regulatory elements are believed to confer risks to various common human diseases (Ernst et al. 2011; Maurano et al. 2012). Therefore, identifying and characterizing the cis-regulatory elements in the human genome have the potential to significantly enhance our ability to link DNA variations to phenotypic traits.

Enhancers are a class of $c i s$-regulatory DNA sequences that play a major role in cell type-specific gene expression during animal development (Levine 2010; Bulger and Groudine 2011). They are capable of modulating the expression of target genes from a distance that could extend more than 1 million base pairs (bp) (Levine et al. 2014). Their mechanisms of function involve the combinatorial binding of sequence-specific transcription factors, which in turn recruit chromatin remodeling com- plexes, alternation of local chromatin structure, formation of chromatin interactions with target gene promoters, and transcriptional initiation or elongation of RNA (Fig. 1; Calo and Wysocka 2013; Smith and Shilatifard 2014). Therefore, recognition of specific enhancer sequences by distinct sets of sequence-specific transcription factors is the primary mechanism by which DNA sequences dictate gene expression programs.

Thanks to the development of high-throughput technologies (Hawkins et al. 2010), hundreds of thousands of candidate enhancers have been annotated in the human genome, compromising at least $12 \%$ of the total DNA sequences (ENCODE Project Consortium 2012; Roadmap Epigenomics Consortium et al. 2015). A majority of these sequences display chromatin accessibility or characteristic patterns of histone modifications in a cell type-specific fashion, supporting their roles in mediating cell type-specific gene expression programs. Further, the sequences are enriched in transcription factor-binding motifs, providing clues to the lineage-specific transcription factors that work at these sequences. Of particular interest to the biomedical researchers, the identified enhancers have been shown to harbor a significant fraction of the noncoding sequence variants associated with increased risks of common human diseases, highlighting the importance of studying these elements in biomedical research (Ernst et al. 2011; Maurano et al. 2012).

Despite these major advances in identifying candidate enhancers in the human genome, a number of important questions remain. For example, what are the biological functions of the annotated enhancers? How do they contribute to cell type-specific gene expression programs? How are their activities regulated in response to extracel- 
I.

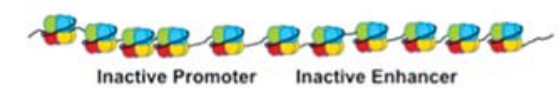

II.

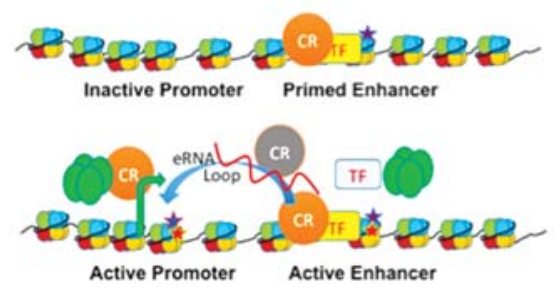

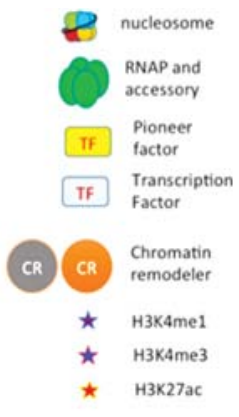

Figure 1. Activation of transcriptional enhancers in the genome. Depicted in this model are three states of enhancers: $(I)$ inactive enhancers are wrapped in nucleosomes; (II) binding of pioneer factors to nucleosomal DNA results in recruitment of chromatin remodeler complexes and the priming of enhancers, characterized by modification of histones (such as H3K4me1) but the absence of active chromatin marks such as histone acetylation (H3K27ac) and destabilization of nucleosomes; (III) binding of additional transcription factors and chromatin remodeling complexes leads to full activation of the enhancers, which are characterized by the acetylation of histones, recruitment of RNA polymerase (RNAP) and accessary factors, production of enhancer RNA (eRNA), and activation of initiation or elongation of transcription at target genes located remotely. Chromatin looping interaction between the enhancer and target promoter is also formed in this process.

lular and intracellular signaling to achieve spatiotemporal regulation of target genes during development? How do sequence variants affect their function and contribute to physiological traits and disease risks? The following sections attempt to provide a general context of the problems and summarize the latest efforts to address these questions.

\section{IDENTIFICATION OF ENHANCERS IN THE GENOME}

Enhancers were initially identified as a class of sequences that can activate a heterologous promoter from a distance in an orientation-independent manner (Banerji et al. 1981; Moreau et al. 1981). This functional definition is not easy to use in the genome-wide identification of enhancers-it is simply impractical to test all human DNA sequences across all cell types in the body under all possible physiological conditions to determine whether any of them functions as an enhancer.

Early on, it was recognized that cis-regulatory sequences including enhancers generally display DNase I hypersensitivity (Tuan and London 1984). This strategy led to the discovery of a number of mammalian enhancers, including the $\beta$-globin locus control region (LCR) (Grosveld et al. 1993; Martin et al. 1996) critical for the developmental control of $\beta$-globin genes in mammals. This approach has undergone several iterations over the years, from the laborious Southern blot analysis (Weintraub and Groudine 1976; Herbomel et al. 1981; Tuan and London 1984) to the high-throughput microarray experiments (Sabo et al. 2006) and the ultrahigh-throughput DNA-sequencing analysis that has been now broadly applied to hundreds of cell types (Boyle et al. 2008; Hesselberth et al. 2009; Maurano et al. 2012; Vierstra et al. 2014). The latest iteration of this assay is the use of a genetically engineered TN5 transpose, instead of DNase I, in a highly streamlined experimental protocol called ATAC-seq (assay for transposase-accessible chromatin with highthroughput sequencing) (Buenrostro et al. 2013) that is especially amendable to very small cell numbers and even single cells (Buenrostro et al. 2015; Cusanovich et al. 2015).

However, DNase I hypersensitivity is not unique to enhancers. Other cis elements such as promoters and insulators also show this property (ENCODE Project Consortium 2012). Therefore, just the presence of DNase I hypersensitivity alone is insufficient to distinguish these different classes of cis elements. Are there other biochemical features that could be used to separate different classes of cis elements?

With the development of ChIP-chip and recently ChIPseq to map transcription factor-binding and chromatin modification patterns in the genome (Kim et al. 2005; Barski et al. 2007; Johnson et al. 2007; Mikkelsen et al. 2007), it was possible to show that promoters, enhancers, and insulators are indeed differentially occupied by transcription factors and are associated with distinct chromatin modification patterns (Heintzman et al. 2007; Kim et al. 2007; Creyghton et al. 2010; Rada-Iglesias et al. 2011). This then allowed genome-wide determination of candidate enhancers. For example, binding sites of p300, a coactivator protein and histone acetyltransferase that acts at enhancers, led to annotation of several thousand enhancers in embryonic brain and limbs in the mouse (Visel et al. 2009). Mapping of DNA occupancy of sequencespecific transcription factors such as Sox2, Oct4, and Nanog also provided the first map of enhancers in the human embryonic stem cells (Boyer et al. 2005; Chen et al. 2008). With the increased understanding of the role of histone modification processes in nucleosome dynamics and chromatin organization, it was natural to examine the chromatin modification patterns in the genome, since different classes of cis elements may recruit different chromatin remodeling proteins that generate distinct patterns of histone modifications. Indeed, this hypothesis was supported by the observation that enhancers are as- 
Table 1. Public resources for enhancer annotations in the human and mouse genomes

\begin{tabular}{|c|c|c|c|}
\hline Species & Paper & Method & Link \\
\hline Human & $\begin{array}{l}\text { Roadmap Epigenomics } \\
\text { Consortium et al. } 2015\end{array}$ & ChromHMM (Ernst and Kellis 2012) & http://egg2.wustl.edu/roadmap/web_portal/ \\
\hline Human & $\begin{array}{l}\text { ENCODE Project } \\
\text { Consortium } 2012\end{array}$ & $\begin{array}{l}\text { Joint call by chromHMM (Ernst and Kellis } \\
2012)+ \text { Segway (Hoffman et al. 2012) }\end{array}$ & $\begin{array}{l}\text { http://genome.ucsc.edu/cgi-bin/hgHubConnect } \\
\text { click Connect: ENCODE Analysis Hub }\end{array}$ \\
\hline Human & Unpublished & $\begin{array}{l}\text { DNase-I hypersensitive sites (DHS) }+ \\
\text { H3K27ac }\end{array}$ & $\begin{array}{l}\text { https://www.encodeproject.org/data/annotations/ } \\
\text { http://promoter.bx.psu.edu/ENCODE/ }\end{array}$ \\
\hline Mouse & Yue e & RFECS (Rajagopal et al. 2013) & http://www.mouseencode.org \\
\hline Human & Andersson et al. 2014 & Cap analysis of gene expression (CAGE) & http://fantom.gsc.riken.jp/5/data/ \\
\hline
\end{tabular}

sociated with high levels of H3K4me1 and low levels of $\mathrm{H} 3 \mathrm{~K} 4 \mathrm{me} 3$, while the opposite is true for promoters (Heintzman et al. 2007). The finding led to the development of chromatin signature-based strategy for mapping enhancers, and identification of such DNA in both mouse and human genomes (Heintzman et al. 2007; Ernst and Kellis 2012; Hoffman et al. 2012; Rajagopal et al. 2013). Computational algorithms have been developed to identify chromatin modification patterns in an unsupervised manner, and then match the different patterns to different classes of candidate functional elements, resulting in a chromatin state-based vocabulary for "reading" the human genome (Hon et al. 2008; Ernst and Kellis 2012). This later strategy has been applied to the chromatin modification maps from more than 120 human tissue and cell types, providing the most comprehensive annotation of the human genome to date (Table 1; Roadmap Epigenom- ics Consortium et al. 2015). Similarly, the same approach has also resulted in mapping of cis elements in the mouse genome (Fig. 2; Table 1; Shen et al. 2012; Yue et al. 2014).

Among the large number of candidate enhancers predicted in the human and mouse genomes, a small fraction of them drew special attention. These sequences, referred to as super-enhancers, are dense clusters of enhancers and are found in virtually every mammalian cell and tissue type examined (Hnisz et al. 2013). They are bound by an extraordinary amount of transcription factors and cofactors and are typically associated with high levels of transcription activities (Whyte et al. 2013) in specific cell types. Found particularly enriched at cell identity genes, super-enhancers are regarded as the key control elements of lineage specification.

Enhancers also show cell type-specific hypomethylation of cytosine (Stadler et al. 2011; Hon et al. 2013;

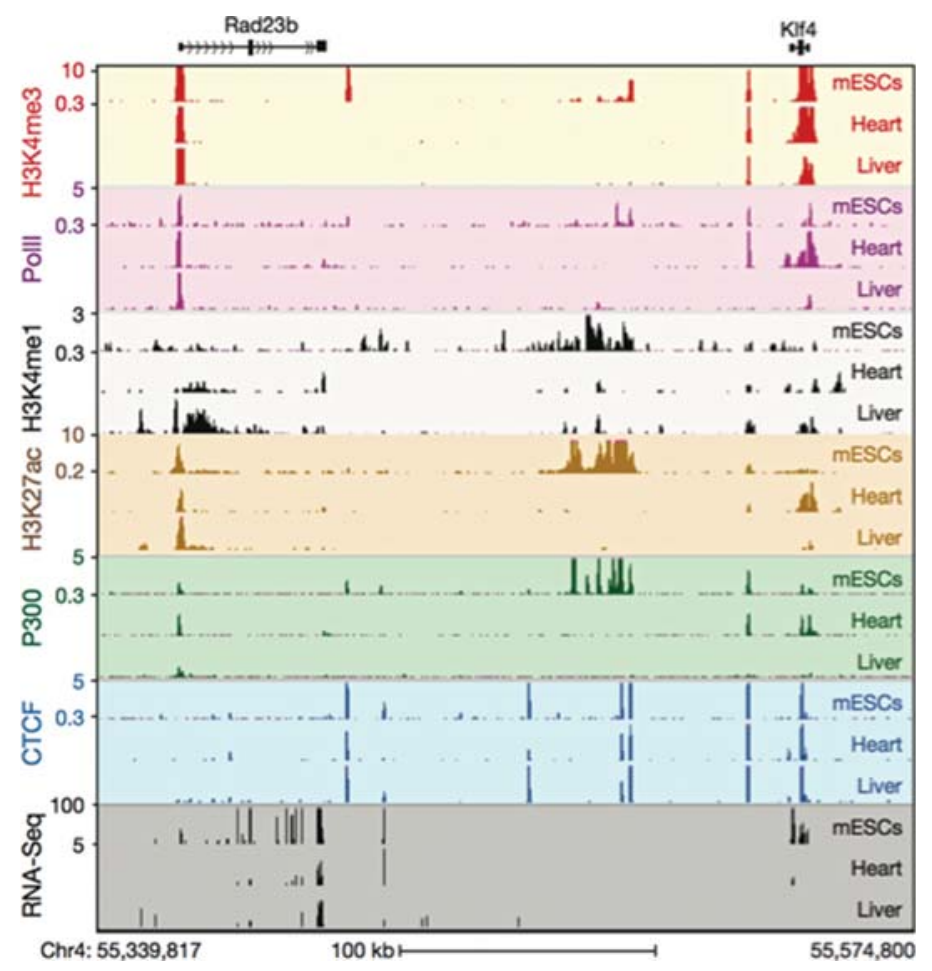

Figure 2. ChIP-seq analysis identifies candidate cis-regulatory elements in the mouse genome. Shown in the UCSC (University of California, Santa Cruz) genome browser are ChIP-seq data for several chromatin modification marks, transcription factor CTCF (CCCTC-binding factor), coactivator protein p300, and RNA polymerase II binding in mouse embryonic stem cell, heart, and liver. The input normalized ChIP-seq data is shown. (Adapted from Shen et al. 2012.) 
Ziller et al. 2013). This DNA hypomethylation at enhancers likely involves oxidization of methylcytosine that is subsequently converted to unmethylated cytosine in a Tet-dependent process ( $\mathrm{Yu}$ et al. 2012; Shen et al. 2013; Song et al. 2013; Hon et al. 2014). Thus, cell type-specific, differentially methylated DNA sequences can be used to define enhancers in different cell types (Stadler et al. 2011; Hon et al. 2013; Ziller et al. 2013; Schultz et al. 2015). Indeed, applying this strategy to several dozen human tissues and cell types, hundreds of thousands of enhancers have been predicted in the human genome and mouse genome (Hon et al. 2013; Ziller et al. 2013; Schultz et al. 2015).

\section{FUNCTIONAL CHARACTERIZATION OF ANNOTATED ENHANCERS}

Now that a large number of candidate enhancers have been annotated in the human genome, the next pressing question is whether these predicted enhancers are truly functional, and, if so, how do they contribute to gene regulation and development. Specifically, in what biological contexts do they function? What genes do they control and how much do they contribute to the target genes' expression in vivo?

Given the large number of candidate enhancers annotated in the human genome, high-throughput assays are needed to characterize the function of these sequences. To this end, massively parallel reporter assays (MPRAs) have been developed to validate the identity of enhancers (Melnikov et al. 2012; Patwardhan et al. 2012; Arnold et al. 2013; Smith et al. 2013; White et al. 2013). MPRA and related methods involve the construction of a library of reporter plasmids containing the test sequence placed either upstream of or downstream from a barcodecontaining reporter gene driven by a heterologous minimal promoter. The barcode sequences, designed to be unique for each tested element, are transcribed along with the reporter gene. Their abundances could be accurately determined by sequencing and used to indicate activities of the corresponding enhancer. Such assays have confirmed that a major fraction of the predicted enhancers are indeed capable of driving reporter genes in cultured cells, providing strong evidence that biochemical signature-defined enhancers are actually what they are thought to be (Kheradpour et al. 2013; Yue et al. 2014).

One drawback of using cultured cells lies in the fact that they are unlikely to fully capture the native context where an enhancer functions. Overcoming this difficulty is the mouse transgenic assays (Pennacchio et al. 2006). In this assay, a reporter construct is injected into fertilized mouse eggs, which are then implanted back into the womb to allow embryonic development to proceed. At a certain developmental stage, say Day 11.5, the embryos are dissected and examined for reporter expression. This assay, although of modest throughput, permits the determination of tissue-specific activities of enhancers in all the embryonic tissues. So far, several thousand ele- ments have been tested in a systematic manner using this strategy, and a database, VISTA enhancer browser, has been set up to distribute the results (Visel et al. 2007). A significant percentage of enhancers predicted using p300 or H3K27ac was shown to possess bona fide enhancer function in vivo (Visel et al. 2009; Nord et al. 2013).

Reporter-based assays, whether in cultured cells or transgenic animals, provide only limited functional information about an enhancer. Neither the target genes of the enhancer nor the degree of transcriptional modulation on target gene expression can be determined. To address this problem, old-fashioned knockout technologies or more recent genome editing approaches are necessary (Attanasio et al. 2013). In particular, the CRISPR/cas9 genome editing technologies have greatly facilitated the deployment of this strategy (Doudna and Charpentier 2014; Shalem et al. 2015). The function of a growing number of candidate enhancers in the mouse genome has now been tested ( $\mathrm{Li}$ et al. 2014; Zhou et al. 2014; Hnisz et al. 2015). One important consideration in the experimental design is to correctly separate direct cis-regulatory effects from indirect effects of down-regulation of the target genes. A strategy to rule out indirect effects involves the construction of reciprocal, monoallelic enhancer deletion and analysis of allelic gene expression patterns in the resulting mutants (Fig. 3). Such analysis was used to determine the mode of cis regulation of Sox 2 by a distal enhancer (Li et al. 2014; Zhou et al. 2014).

With a growing number of enhancers having been investigated in their native contexts, new lessons of enhancer biology are emerging. Results showed that at the Sox 2 gene, an enhancer cluster (referred to as a super-enhancer) plays a primary role for Sox 2 expression in mouse embryonic stem cells (mESCs) (Li et al. 2014; Zhou et al. 2014). Interestingly, other annotated enhancers much closer to Sox2 did not appear to contribute to Sox 2 expression, as no change in Sox 2 transcription was observed on deletion of these elements (Zhou et al. 2014) individually or in combination. This surprising result may suggest that many biochemical signature-defined enhancers may not necessarily function as enhancers in the cells that they were defined in. This result highlights the challenges that face the community about understanding the in vivo function of enhancers. Clearly, much more needs to be done in this area to achieve a more comprehensive understanding of the enhancer function in vivo.

\section{SELECTION OF TARGET GENES FOR ACTIVATION BY ENHANCERS}

Genetic analysis of a family of $\beta$-thalassemia patients provided the first line of evidence that enhancers could function over a long distance on DNA (Kioussis et al. 1983). Now, it is generally accepted that enhancers can activate genes far away, and the targets are not necessarily their immediate neighbors (Levine et al. 2014). Research of the $\beta$-globin gene LCR further indicates that enhancer 


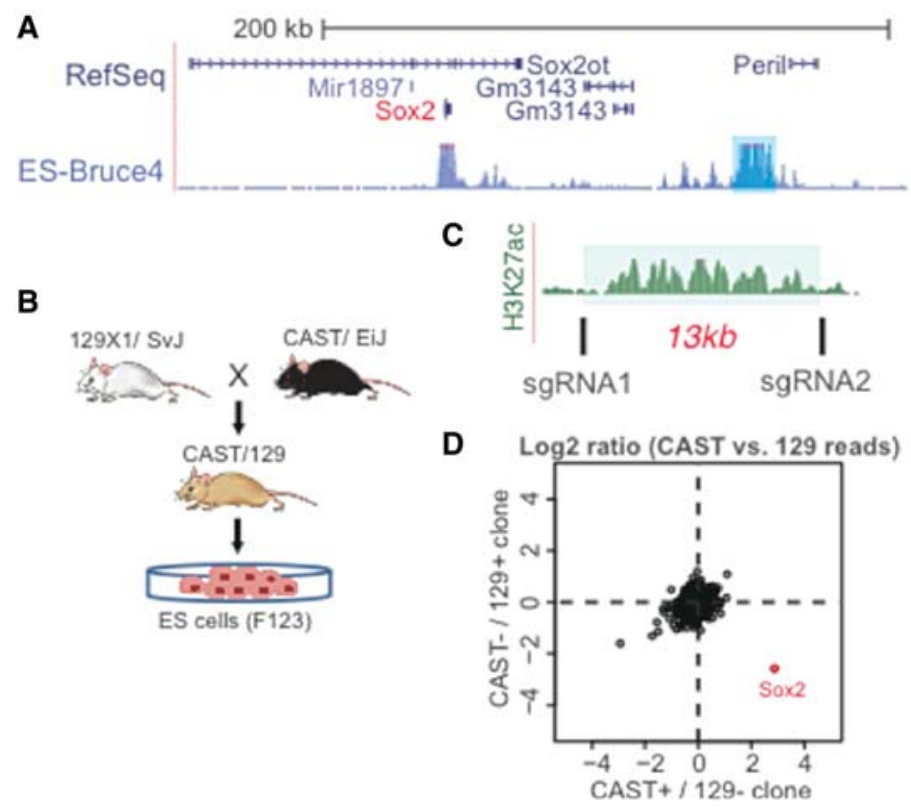

Figure 3. Identification the direct target genes of an enhancer using CRISPR (clustered regularly interspaced short palindromic repeat)/Cas9 genome editing and allelic gene expression analysis. (A) H3K27ac ChIP-seq data over the Sox2 locus. The targeted enhancer is shaded blue. $(B)$ Derivation of hybrid the CAST/129 F123 mouse embryonic stem (ES) cell line for genome editing experiments. (C) Strategy for double CRISPR targeting of a 13-kb enhancer located $130 \mathrm{~kb}$ downstream from the Sox 2 gene. $(D)$ Ratio of Sox 2 gene transcript levels from the CAST and 129 alleles in two experiments where the deletion is on the CAST allele ( $y$-axis) or the 129 allele ( $x$-axis). (Adapted from Li et al. 2014.)

targets may change during development - in fetal tissues, the LCR regulates $\gamma$-globin, but in adult, it controls $\beta$-globin expression (Hanscombe et al. 1991). The mechanisms by which enhancers select their target genes in specific cell type are still incompletely understood.

It is now generally agreed that enhancers achieve long-range regulation of target genes because of spatial proximity formed as a result of the three-dimensional architecture of the chromosome (Levine 2010). Currently, the exact structure of chromosomes, the factors that regulate the organization, and the functions between the chromatin structure and gene expression are being extensively investigated (Gorkin et al. 2014). Much progress has been made in experimentally mapping long-range looping interactions (Fig. 4). The experimental strategies mainly involve chromatin conformation capture (3C)- based methods, including 4C, ChIA-PET, 5C, Hi-C, Capture-C, T2C, DNase-HiC, and, more recently, in situ Hi$\mathrm{C}$ (a version of $\mathrm{Hi}-\mathrm{C}$ in which proximity ligation is performed in situ in permeabilized nuclei) (Dostie et al. 2006; Fullwood et al. 2009; Simonis et al. 2009; Duan et al. 2010; Kalhor et al. 2012; Nagano et al. 2013; Hughes et al. 2014; Kolovos et al. 2014; Rao et al. 2014; Ma et al. 2015). Collectively, data from these different $3 \mathrm{C}$ technologies have allowed researchers to identify general features of genome organization and determine chromatin interactions at increasing resolution (Rao et al. 2014; Hsieh et al. 2015; Ma et al. 2015; Sahlén et al. 2015).

Studies using 3C-based molecular analysis of the 3D genome organization have shown that chromosomes consist of relatively stable chromatin domains, referred to as

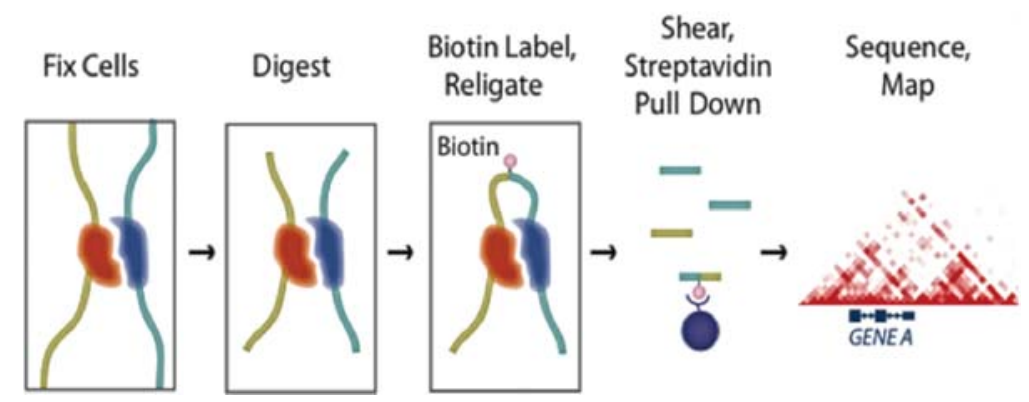

Figure 4. Diagram of a genome-wide 3C (Hi-C) experiment. Cells are fixed with formaldehyde, digested with HindIII restriction enzyme, end labeled with biotin conjugated nucleotides, and relegated. Ligated DNA fragments are isolated by shearing DNA and isolating ligation products using streptavidin-coated beads. DNA is then PCR amplified, sequenced, and mapped to give a comprehensive picture of chromatin interactions. 

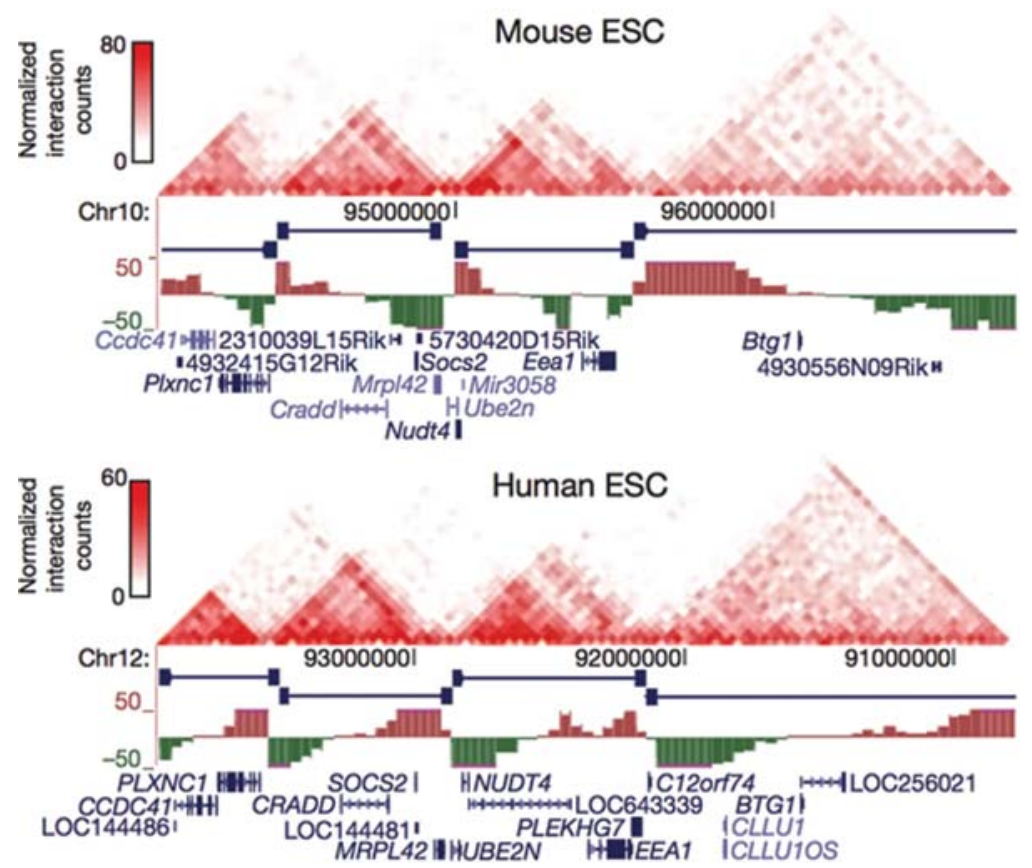

Figure 5. Topologically associated domain (TAD) boundaries are conserved in mouse and human cells. Shown are UCSC genome browser shots of a chromatin contact matrix over a syntenic region in the mouse (upper panel) and human (lower panel) embryonic stem cells (ESC). Locations of the TADs in this region are indicated below each browser shot, along with directionality index as defined in Dixon et al. (2012). (Adapted from Dixon et al. 2012.)

topologically associating domains (TADs) (Fig. 5; Dixon et al. 2012; Nora et al. 2012; Sexton et al. 2012). Although the structure of the TADs can change and disappear during mitosis, they always reestablish the same patterns after each cell division (Naumova et al. 2013). More surprisingly, TADs are largely the same in different cell types and throughout development, and the TAD boundaries are highly conserved between human and mouse (Fig. 5; Dixon et al. 2012; Vietri Rudan et al. 2015). The strong conservation of TADs during evolution suggests that TADs serve important biological roles, and one of them is likely to physically constrain interactions between enhancers and promoters, limiting enhancers to target genes located in the TADs. This hypothesis has received multiple lines of evidence. First, it was shown that correlation of chromatin state at enhancers and promoters is most pronounced within the same TADs (Nora et al. 2012; Shen et al. 2012; Waszak et al. 2015). Second, deletion of TAD boundaries can lead to ectopic interactions between enhancers and noncognate promoters, resulting in misregulation of gene expression in various cell types (Nora et al. 2012; Lupiáñez et al. 2015). Third, TAD boundaries are enriched for binding sites of CTCF protein, a factor previously showed to be essential for function of insulators - a class of cis elements that act to block enhancer/promoter interactions (Dixon et al. 2012; Vietri Rudan et al. 2015). Mutating the CTCFbinding sites at the TAD boundaries or depleting CTCF protein levels both lead to slightly increased inter-TAD interactions, supporting a critical role for this DNA-binding protein in the formation of TADs (Zuin et al. 2014; Narendra et al. 2015).
A computational approach has also been developed to infer the target genes based on the chromatin state and chromatin accessibility in the genome (Ernst et al. 2011; Neph et al. 2012; Shen et al. 2012; Thurman et al. 2012). This strategy assumes that an enhancer and its cognate target(s) would show coordinated transcriptional activities across a large panel of cell types. Based on this assumption, one can examine the large data sets of chromatin accessibility, modifications, and transcription maps to identify the pairs of promoter/enhancer that show significantly correlated patterns of activities. This strategy has resulted in the prediction of enhancer/promoter targets in human and mouse genomes (Neph et al. 2012; Shen et al. 2012; Thurman et al. 2012; Vierstra et al. 2014). Such predictions were supported by chromatin loop data and are found to be well within TADs (Shen et al. 2012). These results support a strong correlation between chromatin interactions and regulatory activities of enhancers. However, more in-depth analyses will be necessary to inform on which strategy works more accurately.

\section{UNDERSTANDING FUNCTIONAL CONSEQUENCES OF DNA VARIATIONS IN ENHANCERS}

A major goal of the recent National Institutes of Health (NIH) Precision Medicine Initiative is to develop disease prevention and treatment strategies that are tailored to each patient's own genetic makeup (Collins and Varmus 2015). To achieve this goal requires a better understand- 
ing of how the unique set of DNA variants in each individual led to the specific phenotypic traits. Enhancers occupy a crucial junction that connects genetic sequences to cellular function and consequently phenotypic traits of each individual. Study of enhancers is an essential component of the efforts to dissect the effects of noncoding variants on gene expression patterns.

Genome-wide association studies (GWASs) have identified a large number of sequence variants in the human genome that are linked to various physiological traits and common diseases. On the one hand, these sequence variants provided clues to the mechanisms by which DNA sequences instruct the phenotypic traits and disease state. On the other hand, interpreting the functional consequences of these variants is still very challenging. This is because most sequence variants found in GWASs reside in noncoding regions of the human genome, where the function remains to be defined. And frequently, the GWAS hits are just in linkage disequilibrium with the true causal variants that remain hidden (Botstein and Risch 2003; Cardon and Abecasis 2003; Carlson et al. 2004; Altshuler et al. 2008; Frazer et al. 2009). Annotation of the large number of enhancers in the human genome has now paved the way for a better understanding the function of these DNA variants. Recent studies using data from ENCODE and Roadmap Epigenome projects have shown that variants in regulatory elements from specific tissues are enriched for related physiological traits and diseases at genome-wide significant association values (ENCODE Project Consortium 2012; Maurano et al. 2012; Roadmap Epigenomics Consortium et al. 2015). This strongly suggests that many sequence variants contribute to phenotype by affecting enhancer functions and likely gene expression.

Additional evidence supporting this hypothesis comes from analysis of allelic gene expression in the human genome. Because the two copies of DNA that each individual inherits from its parents are not identical but contain millions of sequence polymorphisms, it is conceivable that sequence variants that disrupt enhancer function could lead to allelic biases of gene expression. Indeed, widespread allelic biases in transcription have been reported (Dixon et al. 2015; Leung et al. 2015; Waszak et al. 2015). Such biases were recently shown to strongly correlate with allelic biases in histone acetylation at enhancers, supporting the hypothesis that sequence variants may disrupt enhancer function, which in turn affects transcription of target genes (Dixon et al. 2015; Grubert et al. 2015; Leung et al. 2015). Further supporting this hypothesis, allelic biases in histone acetylation at enhancers show a strong and significant correlation with sequence variants that disrupt transcription factor binding to DNA (Grubert et al. 2015; Leung et al. 2015).

Statistical analyses of gene expression patterns in various human cell and tissue types have shown that on average $20 \%-30 \%$ of the variations in gene expression are heritable (Grundberg et al. 2012). Of these, approximately one-third are accounted for by variants acting in cis, whereas the other approximately two-thirds come from variants acting in trans (Price et al. 2011; Grundberg et al. 2012). The observation that factors such as genegene interactions, gene-environmental interactions, and possibly epigenetic mechanisms play a more prominent role in gene expression than direct genetic mechanisms presents substantial challenges in predicting gene expression from sequences. Delineating the exact contribution of each component to gene expression patterns in different cell types is undoubtedly going to require a better understanding of the molecular mechanisms of enhancer function (Albert and Kruglyak 2015; Pai et al. 2015).

\section{CLOSING REMARKS}

Understanding the gene regulatory programs encoded by the human genome is a central objective of biomedical research. Recent advances in the annotation and characterization of enhancers in the human genomes represent a significant step toward this goal. The detailed maps of chromatin state and accessibility across hundreds of cell and tissue types make it possible to study the cell typespecific activities of cis-regulatory elements throughout the genome and generate hypotheses regarding the mechanisms controlling dynamic gene expression programs in different cell types. The catalogs of candidate enhancers and other regulatory elements have become a valuable resource for researchers to decipher the effects of noncoding variants in gene expression and human diseases. The high-throughput methodologies for cis elements mapping and characterization have also provided a powerful approach for investigating the pathogenesis of cancer and other human diseases.

More research is undoubtedly needed to better define the roles of enhancers in gene expression and cellular phenotypes. Specifically, it is necessary to achieve a more quantitative understanding of each enhancer regarding how extracellular and intracellular signaling leads to dynamic transcription factor binding and chromatin remodeling at the element, and how combinatorial binding of transcription factors in turn affects the transcription of the target gene. To this end, an integrative, systems biology approach is necessary. Quantitative and predictive models of gene regulatory networks will need to be developed and tested. Model organisms such as the laboratory mouse, coupled with the CRISPR/cas9 genome engineering, is proving invaluable in this effort because of the possibilities of sorting out causes and effects through genetic manipulations. Additionally, single-cell analyses of transcriptome, DNA methylation, chromatin accessibility, and higher-order organization are emerging as powerful tools to study gene regulation at unprecedented resolutions and details (Tang et al. 2010; Guo et al. 2013; Nagano et al. 2013; Deng et al. 2014; Buenrostro et al. 2015; Cusanovich et al. 2015). Application of these tools will yield more breakthroughs in coming years.

\section{ACKNOWLEDGMENTS}

We thank all the current and previous Ren laboratory members for their contributions to both the method- 
ologies and discoveries described in the text. Research in the Ren laboratory has been generously supported by the Ludwig Institute for Cancer Research, the National Institutes of Health (U54HG006997, U01ES017166, and R01HG003991), and the California Institute of Regenerative Medicine (RN2-00905).

\section{REFERENCES}

Albert FW, Kruglyak L. 2015. The role of regulatory variation in complex traits and disease. Nat Rev Genet 16: 197-212.

Altshuler D, Daly MJ, Lander ES. 2008. Genetic mapping in human disease. Science 322: 881-888.

Andersson R, Gebhard C, Miguel-Escalada I, Hoof I, Bornholdt J, Boyd M, Chen Y, Zhao X, Schmidl C, Suzuki T, et al. 2014. An atlas of active enhancers across human cell types and tissues. Nature 507: 455-461.

Arnold CD, Gerlach D, Stelzer C, Boryn LM, Rath M, Stark A. 2013. Genome-wide quantitative enhancer activity maps identified by STARR-seq. Science 339: 1074-1077.

Attanasio C, Nord AS, Zhu Y, Blow MJ, Li Z, Liberton DK, Morrison H, Plajzer-Frick I, Holt A, Hosseini R, et al. 2013. Fine tuning of craniofacial morphology by distant-acting enhancers. Science 342: 1241006.

Banerji J, Rusconi S, Schaffner W. 1981. Expression of a $\beta$-globin gene is enhanced by remote SV40 DNA sequences. Cell 27: 299-308.

Barski A, Cuddapah S, Cui K, Roh TY, Schones DE, Wang Z, Wei G, Chepelev I, Zhao K. 2007. High-resolution profiling of histone methylations in the human genome. Cell 129: $823-$ 837.

Botstein D, Risch N. 2003. Discovering genotypes underlying human phenotypes: Past successes for Mendelian disease, future approaches for complex disease. Nat Genet 33(Suppl): 228-237.

Boyer LA, Lee TI, Cole MF, Johnstone SE, Levine SS, Zucker JP, Guenther MG, Kumar RM, Murray HL, Jenner RG, et al. 2005. Core transcriptional regulatory circuitry in human embryonic stem cells. Cell 122: 947-956.

Boyle AP, Davis S, Shulha HP, Meltzer P, Margulies EH, Weng Z, Furey TS, Crawford GE. 2008. High-resolution mapping and characterization of open chromatin across the genome. Cell 132: 311-322.

Buenrostro JD, Giresi PG, Zaba LC, Chang HY, Greenleaf WJ. 2013. Transposition of native chromatin for fast and sensitive epigenomic profiling of open chromatin, DNA-binding proteins and nucleosome position. Nat Methods 10: 1213-1218.

Buenrostro JD, Wu B, Litzenburger UM, Ruff D, Gonzales ML, Snyder MP, Chang HY, Greenleaf WJ. 2015. Single-cell chromatin accessibility reveals principles of regulatory variation. Nature 523: 486-490.

Bulger M, Groudine M. 2011. Functional and mechanistic diversity of distal transcription enhancers. Cell 144: 327-339.

Calo E, Wysocka J. 2013. Modification of enhancer chromatin: What, how, and why? Mol Cell 49: 825-837.

Cardon LR, Abecasis GR. 2003. Using haplotype blocks to map human complex trait loci. Trends Genet 19: 135-140.

Carlson CS, Eberle MA, Kruglyak L, Nickerson DA. 2004. Mapping complex disease loci in whole-genome association studies. Nature 429: 446-452.

Chen X, Xu H, Yuan P, Fang F, Huss M, Vega VB, Wong E, Orlov YL, Zhang W, Jiang J, et al. 2008. Integration of external signaling pathways with the core transcriptional network in embryonic stem cells. Cell 133: 1106-1117.

Collins FS, Varmus H. 2015. A new initiative on precision medicine. N Engl J Med 372: 793-795.

Creyghton MP, Cheng AW, Welstead GG, Kooistra T, Carey BW, Steine EJ, Hanna J, Lodato MA, Frampton GM, Sharp PA, et al. 2010. Histone H3K27ac separates active from poised enhancers and predicts developmental state. Proc Natl Acad Sci 107: 21931-21936.
Cusanovich DA, Daza R, Adey A, Pliner HA, Christiansen L, Gunderson KL, Steemers FJ, Trapnell C, Shendure J. 2015. Epigenetics. Multiplex single-cell profiling of chromatin accessibility by combinatorial cellular indexing. Science $\mathbf{3 4 8}$ : 910-914.

Deng Q, Ramsköld D, Reinius B, Sandberg R. 2014. Single-cell RNA-seq reveals dynamic, random monoallelic gene expression in mammalian cells. Science 343: 193-196.

Dixon JR, Selvaraj S, Yue F, Kim A, Li Y, Shen Y, Hu M, Liu JS, Ren B. 2012. Topological domains in mammalian genomes identified by analysis of chromatin interactions. Nature 485: 376-380.

Dixon JR, Jung I, Selvaraj S, Shen Y, Antosiewicz-Bourget JE, Lee AY, Ye Z, Kim A, Rajagopal N, Xie W, et al. 2015. Chromatin architecture reorganization during stem cell differentiation. Nature 518: 331-336.

Dostie J, Richmond TA, Arnaout RA, Selzer RR, Lee WL, Honan TA, Rubio ED, Krumm A, Lamb J, Nusbaum C, et al. 2006. Chromosome Conformation Capture Carbon Copy (5C): A massively parallel solution for mapping interactions between genomic elements. Genome Res 16: 1299-1309.

Doudna JA, Charpentier E. 2014. Genome editing. The new frontier of genome engineering with CRISPR-Cas9. Science 346: 1258096.

Duan Z, Andronescu M, Schutz K, McIlwain S, Kim YJ, Lee C, Shendure J, Fields S, Blau CA, Noble WS. 2010. A three-dimensional model of the yeast genome. Nature 465: $363-367$.

ENCODE Project Consortium. 2012. An integrated encyclopedia of DNA elements in the human genome. Nature 489: $57-$ 74.

Ernst J, Kellis M. 2012. ChromHMM: Automating chromatinstate discovery and characterization. Nat Methods 9: 215216.

Ernst J, Kheradpour P, Mikkelsen TS, Shoresh N, Ward LD, Epstein CB, Zhang X, Wang L, Issner R, Coyne M, et al. 2011. Mapping and analysis of chromatin state dynamics in nine human cell types. Nature 473: 43-49.

Frazer KA, Murray SS, Schork NJ, Topol EJ. 2009. Human genetic variation and its contribution to complex traits. Nat Rev Genet 10: 241-251.

Fullwood MJ, Liu MH, Pan YF, Liu J, Xu H, Mohamed YB, Orlov YL, Velkov S, Ho A, Mei PH, et al. 2009. An oestrogen-receptor- $\alpha$-bound human chromatin interactome. Nature 462: $58-64$.

Gorkin DU, Leung D, Ren B. 2014. The 3D genome in transcriptional regulation and pluripotency. Cell Stem Cell 14: $762-775$.

Grosveld F, Antoniou M, Berry M, de Boer E, Dillon N, Ellis J, Fraser P, Hurst J, Imam A, Meijer D, et al. 1993. Regulation of human globin gene switching. Cold Spring Harb Symp Quant Biol 58: 7-13.

Grubert F, Zaugg JB, Kasowski M, Ursu O, Spacek DV, Martin AR, Greenside P, Srivas R, Phanstiel DH, Pekowska A, et al. 2015. Genetic control of chromatin states in humans involves local and distal chromosomal interactions. Cell 162: $1051-$ 1065.

Grundberg E, Small KS, Hedman ÅK, Nica AC, Buil A, Keildson S, Bell JT, Yang TP, Meduri E, Barrett A, et al. 2012. Mapping cis- and trans-regulatory effects across multiple tissues in twins. Nat Genet 44: 1084-1089.

Guo H, Zhu P, Wu X, Li X, Wen L, Tang F. 2013. Single-cell methylome landscapes of mouse embryonic stem cells and early embryos analyzed using reduced representation bisulfite sequencing. Genome Res 23: 2126-2135.

Hanscombe O, Whyatt D, Fraser P, Yannoutsos N, Greaves D, Dillon N, Grosveld F. 1991. Importance of globin gene order for correct developmental expression. Genes Dev 5: $1387-$ 1394.

Hawkins RD, Hon GC, Ren B. 2010. Next-generation genomics: An integrative approach. Nat Rev Genet 11: 476-486.

Heintzman ND, Stuart RK, Hon G, Fu Y, Ching CW, Hawkins RD, Barrera LO, Van Calcar S, Qu C, Ching KA, et al. 2007. 
Distinct and predictive chromatin signatures of transcriptional promoters and enhancers in the human genome. Nat Genet 39: $311-318$

Herbomel P, Saragosti S, Blangy D, Yaniv M. 1981. Fine structure of the origin-proximal DNAase I-hypersensitive region in wild-type and EC mutant polyoma. Cell 25: 651-658.

Hesselberth JR, Chen X, Zhang Z, Sabo PJ, Sandstrom R, Reynolds AP, Thurman RE, Neph S, Kuehn MS, Noble WS, et al. 2009. Global mapping of protein-DNA interactions in vivo by digital genomic footprinting. Nat Methods 6: 283-289.

Hnisz D, Abraham BJ, Lee TI, Lau A, Saint-André V, Sigova AA, Hoke HA, Young RA. 2013. Super-enhancers in the control of cell identity and disease. Cell 155: 934-947.

Hnisz D, Schuijers J, Lin CY, Weintraub AS, Abraham BJ, Lee TI, Bradner JE, Young RA. 2015. Convergence of developmental and oncogenic signaling pathways at transcriptional super-enhancers. Mol Cell 58: 362-370.

Hoffman MM, Buske OJ, Wang J, Weng Z, Bilmes JA, Noble WS. 2012. Unsupervised pattern discovery in human chromatin structure through genomic segmentation. Nat Methods 9: $473-476$.

Hon G, Ren B, Wang W. 2008. ChromaSig: A probabilistic approach to finding common chromatin signatures in the human genome. PLoS Comput Biol 4: e1000201.

Hon GC, Rajagopal N, Shen Y, McCleary DF, Yue F, Dang MD, Ren B. 2013. Epigenetic memory at embryonic enhancers identified in DNA methylation maps from adult mouse tissues. Nat Genet 45: 1198-1206.

Hon GC, Song CX, Du T, Jin F, Selvaraj S, Lee AY, Yen CA, Ye Z, Mao SQ, Wang BA, et al. 2014. $5 \mathrm{mC}$ oxidation by Tet 2 modulates enhancer activity and timing of transcriptome reprogramming during differentiation. Mol Cell 56: 286-297.

Hsieh TH, Weiner A, Lajoie B, Dekker J, Friedman N, Rando OJ. 2015. Mapping nucleosome resolution chromosome folding in yeast by micro-C. Cell 162: 108-119.

Hughes JR, Roberts N, McGowan S, Hay D, Giannoulatou E, Lynch M, De Gobbi M, Taylor S, Gibbons R, Higgs DR. 2014. Analysis of hundreds of cis-regulatory landscapes at high resolution in a single, high-throughput experiment. Nat Genet 46: 205-212.

Johnson DS, Mortazavi A, Myers RM, Wold B. 2007. Genomewide mapping of in vivo protein-DNA interactions. Science 316: $1497-1502$.

Kalhor R, Tjong H, Jayathilaka N, Alber F, Chen L. 2012. Genome architectures revealed by tethered chromosome conformation capture and population-based modeling. Nat Biotechnol 30: 90-98.

Kheradpour P, Ernst J, Melnikov A, Rogov P, Wang L, Zhang X, Alston J, Mikkelsen TS, Kellis M. 2013. Systematic dissection of regulatory motifs in 2000 predicted human enhancers using a massively parallel reporter assay. Genome Res 23: $800-811$.

Kim TH, Barrera LO, Zheng M, Qu C, Singer MA, Richmond TA, Wu Y, Green RD, Ren B. 2005. A high-resolution map of active promoters in the human genome. Nature 436: 876880 .

Kim TH, Abdullaev ZK, Smith AD, Ching KA, Loukinov DI, Green RD, Zhang MQ, Lobanenkov VV, Ren B. 2007. Analysis of the vertebrate insulator protein CTCF-binding sites in the human genome. Cell 128: 1231-1245.

Kioussis D, Vanin E, deLange T, Flavell RA, Grosveld FG. 1983. $\beta$-Globin gene inactivation by DNA translocation in $\gamma \beta$-thalassaemia. Nature 306: 662-666.

Kolovos P, van de Werken HJ, Kepper N, Zuin J, Brouwer RW, Kockx CE, Wendt KS, van IJcken WFJ, Grosveld F, Knoch TA. 2014. Targeted Chromatin Capture (T2C): A novel high resolution high throughput method to detect genomic interactions and regulatory elements. Epigenetics Chromatin 7: 10 .

Lander ES. 2011. Initial impact of the sequencing of the human genome. Nature 470: 187-197.

Leung D, Jung I, Rajagopal N, Schmitt A, Selvaraj S, Lee AY, Yen CA, Lin S, Lin Y, Qiu Y, et al. 2015. Integrative analysis of haplotype-resolved epigenomes across human tissues. $\mathrm{Na}$ ture 518: $350-354$.

Levine M. 2010. Transcriptional enhancers in animal development and evolution. Curr Biol 20: R754-R763.

Levine M, Cattoglio C, Tjian R. 2014. Looping back to leap forward: Transcription enters a new era. Cell 157: 13-25.

Li Y, Rivera CM, Ishii H, Jin F, Selvaraj S, Lee AY, Dixon JR, Ren B. 2014. CRISPR reveals a distal super-enhancer required for Sox 2 expression in mouse embryonic stem cells. PLoS One 9: e114485.

Lupiáñez DG, Kraft K, Heinrich V, Krawitz P, Brancati F, Klopocki E, Horn D, Kayserili H, Opitz JM, Laxova R, et al. 2015. Disruptions of topological chromatin domains cause pathogenic rewiring of gene-enhancer interactions. Cell 161: $1012-1025$.

Ma W, Ay F, Lee C, Gulsoy G, Deng X, Cook S, Hesson J, Cavanaugh C, Ware CB, Krumm A, et al. 2015. Finescale chromatin interaction maps reveal the cis-regulatory landscape of human lincRNA genes. Nat Methods 12: 71-78.

Martin DI, Fiering S, Groudine M. 1996. Regulation of $\beta$-globin gene expression: Straightening out the locus. Curr Opin Genet Dev 6: 488-495.

Maurano MT, Humbert R, Rynes E, Thurman RE, Haugen E, Wang H, Reynolds AP, Sandstrom R, Qu H, Brody J, et al. 2012. Systematic localization of common disease-associated variation in regulatory DNA. Science 337: 1190-1195.

Melnikov A, Murugan A, Zhang X, Tesileanu T, Wang L, Rogov P, Feizi S, Gnirke A, Callan CG Jr, Kinney JB, et al. 2012. Systematic dissection and optimization of inducible enhancers in human cells using a massively parallel reporter assay. Nat Biotechnol 30: 271-277.

Mikkelsen TS, Ku M, Jaffe DB, Issac B, Lieberman E, Giannoukos G, Alvarez P, Brockman W, Kim TK, Koche RP, et al. 2007. Genome-wide maps of chromatin state in pluripotent and lineage-committed cells. Nature 448: 553-560.

Moreau P, Hen R, Wasylyk B, Everett R, Gaub MP, Chambon P. 1981. The SV40 72 base repair repeat has a striking effect on gene expression both in SV40 and other chimeric recombinants. Nucleic Acids Res 9: 6047-6068.

Nagano T, Lubling Y, Stevens TJ, Schoenfelder S, Yaffe E, Dean W, Laue ED, Tanay A, Fraser P. 2013. Single-cell Hi$\mathrm{C}$ reveals cell-to-cell variability in chromosome structure. Nature 502: 59-64.

Narendra V, Rocha PP, An D, Raviram R, Skok JA, Mazzoni EO, Reinberg D. 2015. Transcription. CTCF establishes discrete functional chromatin domains at the Hox clusters during differentiation. Science 347: 1017-1021.

Naumova N, Imakaev M, Fudenberg G, Zhan Y, Lajoie BR, Mirny LA, Dekker J. 2013. Organization of the mitotic chromosome. Science 342: 948-953.

Neph S, Stergachis AB, Reynolds A, Sandstrom R, Borenstein E, Stamatoyannopoulos JA. 2012. Circuitry and dynamics of human transcription factor regulatory networks. Cell 150: 1274-1286.

Nora EP, Lajoie BR, Schulz EG, Giorgetti L, Okamoto I, Servant N, Piolot T, van Berkum NL, Meisig J, Sedat J, et al. 2012. Spatial partitioning of the regulatory landscape of the X-inactivation centre. Nature 485: $381-385$.

Nord AS, Blow MJ, Attanasio C, Akiyama JA, Holt A, Hosseini R, Phouanenavong S, Plajzer-Frick I, Shoukry M, Afzal V, et al. 2013. Rapid and pervasive changes in genome-wide enhancer usage during mammalian development. Cell 155: $1521-1531$.

Pai AA, Pritchard JK, Gilad Y. 2015. The genetic and mechanistic basis for variation in gene regulation. PLoS Genet 11: e1004857.

Patwardhan RP, Hiatt JB, Witten DM, Kim MJ, Smith RP, May D, Lee C, Andrie JM, Lee SI, Cooper GM, et al. 2012. Massively parallel functional dissection of mammalian enhancers in vivo. Nat Biotechnol 30: 265-270.

Pennacchio LA, Ahituv N, Moses AM, Prabhakar S, Nobrega MA, Shoukry M, Minovitsky S, Dubchak I, Holt A, Lewis 
$\mathrm{KD}$, et al. 2006. In vivo enhancer analysis of human conserved non-coding sequences. Nature 444: 499-502.

Price AL, Helgason A, Thorleifsson G, McCarroll SA, Kong A, Stefansson K. 2011. Single-tissue and cross-tissue heritability of gene expression via identity-by-descent in related or unrelated individuals. PLoS Genet 7: e1001317.

Rada-Iglesias A, Bajpai R, Swigut T, Brugmann SA, Flynn RA, Wysocka J. 2011. A unique chromatin signature uncovers early developmental enhancers in humans. Nature 470: 279283.

Rajagopal N, Xie W, Li Y, Wagner U, Wang W, Stamatoyannopoulos J, Ernst J, Kellis M, Ren B. 2013. RFECS: A randomforest based algorithm for enhancer identification from chromatin state. PLoS Comput Biol 9: e1002968.

Rao SS, Huntley MH, Durand NC, Stamenova EK, Bochkov ID, Robinson JT, Sanborn AL, Machol I, Omer AD, Lander ES, et al. 2014. A 3D map of the human genome at kilobase resolution reveals principles of chromatin looping. Cell 159: $1665-1680$.

Roadmap Epigenomics Consortium, Kundaje A, Meuleman W, Ernst J, Bilenky M, Yen A, Heravi-Moussavi A, Kheradpour $\mathrm{P}$, Zhang Z, Wang J, et al. 2015. Integrative analysis of 111 reference human epigenomes. Nature 518: 317-330.

Sabo PJ, Kuehn MS, Thurman R, Johnson BE, Johnson EM, Cao H, Yu M, Rosenzweig E, Goldy J, Haydock A, et al. 2006. Genome-scale mapping of DNase I sensitivity in vivo using tiling DNA microarrays. Nat Methods 3: 511-518.

Sahlén P, Abdullayev I, Ramsköld D, Matskova L, Rilakovic N, Lötstedt B, Albert TJ, Lundeberg J, Sandberg R. 2015. Genome-wide mapping of promoter-anchored interactions with close to single-enhancer resolution. Genome Biol 16: 156.

Schultz MD, He Y, Whitaker JW, Hariharan M, Mukamel EA, Leung D, Rajagopal N, Nery JR, Urich MA, Chen H, et al. 2015. Human body epigenome maps reveal noncanonical DNA methylation variation. Nature 523: 212-216.

Sexton T, Yaffe E, Kenigsberg E, Bantignies F, Leblanc B, Hoichman M, Parrinello H, Tanay A, Cavalli G. 2012. Three-dimensional folding and functional organization principles of the Drosophila genome. Cell 148: 458-472.

Shalem O, Sanjana NE, Zhang F. 2015. High-throughput functional genomics using CRISPR-Cas9. Nat Rev Genet 16: 299-311.

Shen Y, Yue F, McCleary DF, Ye Z, Edsall L, Kuan S, Wagner U, Dixon J, Lee L, Lobanenkov VV, et al. 2012. A map of the cis-regulatory sequences in the mouse genome. Nature 488: $116-120$.

Shen L, Wu H, Diep D, Yamaguchi S, D'Alessio AC, Fung HL, Zhang K, Zhang Y. 2013. Genome-wide analysis reveals TET- and TDG-dependent 5-methylcytosine oxidation dynamics. Cell 153: 692-706.

Simonis M, Klous P, Homminga I, Galjaard RJ, Rijkers EJ, Grosveld F, Meijerink JP, de Laat W. 2009. High-resolution identification of balanced and complex chromosomal rearrangements by 4C technology. Nat Methods 6: 837-842.

Smith E, Shilatifard A. 2014. Enhancer biology and enhanceropathies. Nat Struct Mol Biol 21: 210-219.

Smith RP, Taher L, Patwardhan RP, Kim MJ, Inoue F, Shendure J, Ovcharenko I, Ahituv N. 2013. Massively parallel decoding of mammalian regulatory sequences supports a flexible organizational model. Nat Genet 45: 1021-1028.

Song CX, Szulwach KE, Dai Q, Fu Y, Mao SQ, Lin L, Street C, Li Y, Poidevin M, Wu H, et al. 2013. Genome-wide profiling of 5-formylcytosine reveals its roles in epigenetic priming. Cell 153: 678-691.

Stadler MB, Murr R, Burger L, Ivanek R, Lienert F, Schöler A, van Nimwegen E, Wirbelauer C, Oakeley EJ, Gaidatzis D, et al. 2011. DNA-binding factors shape the mouse methylome at distal regulatory regions. Nature 480: 490-495.

Tang F, Barbacioru C, Bao S, Lee C, Nordman E, Wang X, Lao K, Surani MA. 2010. Tracing the derivation of embryonic stem cells from the inner cell mass by single-cell RNA-Seq analysis. Cell Stem Cell 6: 468-478.

Thurman RE, Rynes E, Humbert R, Vierstra J, Maurano MT, Haugen E, Sheffield NC, Stergachis AB, Wang H, Vernot B, et al. 2012. The accessible chromatin landscape of the human genome. Nature 489: 75-82.

Tuan D, London IM. 1984. Mapping of DNase I-hypersensitive sites in the upstream DNA of human embryonic $\varepsilon$-globin gene in K562 leukemia cells. Proc Natl Acad Sci 81: 27182722.

Vierstra J, Rynes E, Sandstrom R, Zhang M, Canfield T, Hansen RS, Stehling-Sun S, Sabo PJ, Byron R, Humbert R, et al. 2014. Mouse regulatory DNA landscapes reveal global principles of cis-regulatory evolution. Science 346: $1007-$ 1012.

Vietri Rudan M, Barrington C, Henderson S, Ernst C, Odom DT, Tanay A, Hadjur S. 2015. Comparative Hi-C reveals that CTCF underlies evolution of chromosomal domain architecture. Cell Rep 10: 1297-1309.

Visel A, Minovitsky S, Dubchak I, Pennacchio LA. 2007. VISTA Enhancer Browser-A database of tissue-specific human enhancers. Nucleic Acids Res 35: D88-D92.

Visel A, Blow MJ, Li Z, Zhang T, Akiyama JA, Holt A, PlajzerFrick I, Shoukry M, Wright C, Chen F, et al. 2009. ChIP-seq accurately predicts tissue-specific activity of enhancers. $\mathrm{Na}$ ture 457: $854-858$.

Waszak SM, Delaneau O, Gschwind AR, Kilpinen H, Raghav SK, Witwicki RM, Orioli A, Wiederkehr M, Panousis NI, Yurovsky A, et al. 2015. Population variation and genetic control of modular chromatin architecture in humans. Cell 162: $1039-1050$.

Weintraub H, Groudine M. 1976. Chromosomal subunits in active genes have an altered conformation. Science 193: $848-$ 856.

White MA, Myers CA, Corbo JC, Cohen BA. 2013. Massively parallel in vivo enhancer assay reveals that highly local features determine the cis-regulatory function of ChIP-seq peaks. Proc Natl Acad Sci 110: 11952-11957.

Whyte WA, Orlando DA, Hnisz D, Abraham BJ, Lin CY, Kagey MH, Rahl PB, Lee TI, Young RA. 2013. Master transcription factors and mediator establish super-enhancers at key cell identity genes. Cell 153: 307-319.

Yu M, Hon GC, Szulwach KE, Song CX, Zhang L, Kim A, Li X, Dai Q, Shen Y, Park B, et al. 2012. Base-resolution analysis of 5-hydroxymethylcytosine in the mammalian genome. Cell 149: 1368-1380.

Yue F, Cheng Y, Breschi A, Vierstra J, Wu W, Ryba T, Sandstrom R, Ma Z, Davis C, Pope BD, et al. 2014. A comparative encyclopedia of DNA elements in the mouse genome. Nature 515: 355-364.

Zhou HY, Katsman Y, Dhaliwal NK, Davidson S, Macpherson NN, Sakthidevi M, Collura F, Mitchell JA. 2014. A Sox2 distal enhancer cluster regulates embryonic stem cell differentiation potential. Genes Dev 28: 2699-2711.

Ziller MJ, Gu H, Müller F, Donaghey J, Tsai LT, Kohlbacher O, De Jager PL, Rosen ED, Bennett DA, Bernstein BE, et al. 2013. Charting a dynamic DNA methylation landscape of the human genome. Nature 500: 477-481.

Zuin J, Dixon JR, van der Reijden MIJA, Ye Z, Kolovos P, Brouwer RWW, van de Corput MPC, van de Werken HJG, Knoch TA, van IJcken WFJ, et al. 2014. Cohesin and CTCF differentially affect chromatin architecture and gene expression in human cells. Proc Natl Acad Sci 111: 996-1001. 


\section{$\$_{\text {CSH\& }}^{\infty}$ Cold Spring Harbor Symposia SYMPOSIA On Quantitative Biology}

\section{Transcriptional Enhancers: Bridging the Genome and Phenome}

Bing Ren and Feng Yue

Cold Spring Harb Symp Quant Biol 2015 80: 17-26 originally published online November 18, 2015

Access the most recent version at doi:10.1101/sqb.2015.80.027219

References This article cites 110 articles, 22 of which can be accessed free at: http://symposium.cshlp.org/content/80/17.full.html\#ref-list-1

\section{License}

Email Alerting Receive free email alerts when new articles cite this article - sign up in Service the box at the top right corner of the article or click here. 